\title{
Estimation of Sterilization Value using General Method and Ball Formula for Beef Rendang in Retort Pouch
}

\author{
Anggita Sari Praharasti ${ }^{\mathrm{a}, 1}$, Annisa Kusumaningrum ${ }^{\mathrm{a}, 2}$, Asep Nurhikmat ${ }^{\mathrm{a}, 3}$, Agus Susanto ${ }^{\mathrm{a}, 4}$, Suprapedi ${ }^{\mathrm{b}}$, \\ Maghfira Dwi Maulani ${ }^{\mathrm{c}}$, Wahyu Wiratama ${ }^{\mathrm{d}}$ \\ ${ }^{a}$ Research Unit for Natural Product Technology, Indonesian Institute of Science, Yogyakarta, 55861, Indonesia \\ E-mail: ${ }^{1}$ praharasti@gmail.com, ${ }^{2}$ nisa.ksmningrum@gmail.com, ${ }^{3}$ asep.nurhikmat@yahoo.com, ${ }^{4}$ agussusanto888@ymail.com \\ ${ }^{b}$ Research Center for Physics, Indonesian Institute of Sciences, Banten, 15314, Indonesia \\ E-mail: suprapu@gmail.com \\ ${ }^{c}$ Department of Food Science and Technology, Faculty of Agriculture, Universitas Sebelas Maret, Surakarta, 57126, Indonesia \\ E-mail: dwimaghfira@gmail.com \\ ${ }^{d}$ Department of Agriculture Engineering, Faculty of Agriculture, Universitas Lampung, Bandar Lampung, 35145, Indonesia \\ E-mail: wahyuwiratama23@gmail.com
}

\begin{abstract}
The existence of a ready-to-eat meal with a long shelf life is essential, particularly for emergency food and military diet, as well as for alternative food for modern society. Rendang is a well-known Indonesian traditional food which may be packaged in a retort bag by employing a sterilization process. The sterilization value of Rendang is presently still limited. This study aimed to estimate sterilization value or heat sufficiency $\left(F_{0}\right)$ using the General Method and the Ball Formula Method. The estimated value was then compared with the value obtained from the experiment. It was further used to predict process time $\left(P_{t}\right)$ to minimize the need for trial optimization on the product. The thermal sterilization process was carried out using a horizontal retort with a pressure of 1.3 bar for 40 minutes. The results showed that the $F_{0}$ values predicted were in a close agreement with the observed (experimental) values. $F_{0}$ values were 5.88, 5.17, and 5.91 minutes for the General Method, Formula Method, and the observation, respectively. The $P_{t}$ values of Beef Rendang in a retort bag with $F_{0}$ values of $4,5,8,10$, and 12 minutes were 25, 27, 31, 34, and 36 minutes for retort temperature of $123^{\circ} \mathrm{C}$, respectively. Whereas for a retort temperature of $121^{\circ} \mathrm{C}$, the $P_{t}$ values were $28,30,36,39$, and 42 minutes, respectively. In conclusion, both the General Method and Ball Formula are accurate to estimate the sterilization value of Beef Rendang packaged in Retort Pouch.
\end{abstract}

Keywords — sterilization; beef rendang; retort bag; ball formula method; $\mathbf{F}_{0}$ value.

\section{INTRODUCTION}

The sterilization process for ready-to-eat foods in the form of cans or retort bags was well-known as a solution to extend shelf life. The sterilization process is suitable for lowacid food categories, which generally have a short life period. Packaging with Retort bags for the past few years has begun to be high in demand because it is considered more userfriendly and eco-friendlier. There were many studies about retort pouch packaging study in many aspects. The reviews are about the $\mathrm{F}_{0}$ value; the sensory and physicochemical affects the process; the shelf-life time prediction of the products; and even the potentials ready-to-eat retort pouch products for space missions.

Many researchers had studied food packaging techniques using retort pouches include Dinakaran et al. [1]. The latter studied the Ready to eat Cassava (Manihot esculenta Crantz) inside See Trough Pouch by hot filling using a brine solution. $\mathrm{F}_{0}$ value of 7 was the optimum for the product with a shelf life of 75 days for the product. To get the longer shelf-life time, Dinakaran et al. [2] used Curcumin addition and found that the $F_{0}$ value was 8.97 minutes with a shelf life of 12 months under ambient temperature. Mugale et al. [3] were also study sterilization of Eel Curry in a four-layered laminated retort pouch consists of 12-micron polyester/9 micron aluminum foil $/ 5$ micron nylon/70 micron cast polypropylene with the size of $150 \times 200 \mathrm{~mm}$ using steam air retort at $121^{\circ} \mathrm{C}$. A product that has $\mathrm{F}_{0}$ value of 12,89 minutes, the total process time of 55 minutes, and cook value of 97,65 minutes had better textural and sensory quality and the shelf life was reported 7 months at ambient temperature $30 \pm 2{ }^{\circ} \mathrm{C}$. Palak paneer as one of Indian dish was also studied 
it's heat penetration characteristic by Thakur and Rai [4] using a temperature $110-125^{\circ} \mathrm{C}$ for $10-25$ minutes with a horizontal stationary air-steam retort. $\mathrm{J}_{\mathrm{h}}$ value were in the amount of $(0,25-1,939), f_{h}(3,43-16,22$ minutes $), j_{c}(0,65-$ 1,31 ), and total process time $\mathrm{B}$ was 7,9-32,5 minutes for $\mathrm{F}_{0}$ value of $2,81-55,19$ minutes. They found that processing time of 10 at $116^{\circ} \mathrm{C}$ gave an acceptable product. Girish et al. [5] developed shelf-stable Pork Curry inside the retort pouch using a retort temperature of $121^{\circ} \mathrm{C}$ with the maintained pressure at $20 \pm 1$ psi. $\mathrm{F}_{0}$ value of the product was 11,81 with a total process time of 48 minutes, and the storage time was six months at ambient temperature. Rogan Josh, as one of the traditional meat products from Kashmir India, was also packed in a retort pouch by Ahmad et al. [6]. They used retort at $121^{\circ} \mathrm{C}$ with $\mathrm{F}_{0}$ value of 7-11 minutes and then stored at ambient temperature to study the quality characteristics such as $\mathrm{pH}$, shear force, sensory attributes, free fatty acid content, and thiobarbituric acid reactive substances. The result showed that a product with $\mathrm{F}_{0}$ value of 9 was the highest overall acceptability with a shelf-life time of 12 months.

Research on sterilization food had developed in a variety of packaging, whether it is cans and flexible pouch bags [7][12]. Studies on food preservation using packaging technology had been developed in some methods, such as sterilization using steam sterilization, HPP, pasteurization, osmotic pressure, radio frequency usage, Microwaveassisted thermal sterilization system (MATS), until the user of thermal sterilization for High-moisture snack. Research is done by Isaka et al. [13] examined the effect of high-speed shear treatment in rice gel samples stored at $25^{\circ} \mathrm{C}$ for two months. The results showed that the properties of HST rice gels were affected by retort treatment in the aspects of starch retrogradation and other factors such as the change of protein. The novel finding of food preservation includes the use of $\mathrm{ZnO}$ nanoparticles combined with radiofrequency (ZNCRF), which had been studied by Xu et al. [14], [15] using Twice-cooked pork dish and Stewed pork with carrots, respectively. ZNCRF pasteurization had better preserved than those processed with High-Pressure Steam (HPS). The method for the pasteurization technique for food was also studied by Condon et al. [16]. To produce the high quality of Ready-to-eat whole edible Crab (Cancer Pagurus), it should be in temperatures between $104-108^{\circ} \mathrm{C}$ for $400-800 \mathrm{~g}$ of crabs, respectively. The other novel method was headspace fingerprint, which was developed by Grauwet and Shpigelman [17] as a potential multivariate intrinsic indicator for monitoring temperature variation in nonuniformity heat transfer in the retort or a pack. Packaging technology in the aspect of different $\mathrm{O}_{2}$ permeability was also studied by Romero et al. [18] for Black ripe olives in retort-able pouches. The color of the product slightly changes after five months of storage for those without iron addition packed in jars. Similar behavior also occurred in a product which packaged in a retort pouch with an oxygen permeability of films lower than $82 \mathrm{~cm}^{3} / \mathrm{m}^{2} /$ day. For ready to eat Fish-incorporated noodle products, it was also being examined by Kamalakanth et al. [19], which discovered that during storage, the lightness was decreased. The yellowness, redness, and trend of hardness were increased. The product had a shelf life of 90 days at ambient temperature $\left(28 \pm 2^{\circ} \mathrm{C}\right)$.
Microwave-assisted thermal sterilization system (MATS) as food packaging technology was also studied by Patel et al. [20] and Soni et al. [21], which claim could have better sensory qualities and attribute related to consumer acceptance. Besides sterilized as ready to eat products, another alternative technology of osmotic pressure usage was also one of a promising method for the preservation of meat in new condition [22]. For High-moisture snack foods, the use of thermal sterilization had also been studied by Ai et al. [23] for the aspect of B. cereus spores inactivation compared to the usage of boiling water and autoclave system. An increase in the heat transfer coefficient can be used to improve inactivation. Those were via flow dynamics and processing temperature.

Soya peas curry as a retort food from India had been evaluated in the area of shelf life and food safety by Abhishek et al. [8]. They examined the parameters of the thermal process like retort temperature, heating lag factor $\left(\mathrm{J}_{\mathrm{h}}\right)$, heating rate index $\left(\mathrm{f}_{\mathrm{h}}\right)$, process time $(\mathrm{B}), \mathrm{F}_{0}$ value, and cook value. The product remained in good condition after 9 months of storage. Mary et al. [7] also examined the milkfish (Chanos chanos) from Kochi, Kerala, India, in the field of a heat penetration test compared to the use of the steam-air application and water immersion. The result of the research was CUT value was achieved in less time for steam air rather than water immersion. The advantage of steam-air retort had clearly described in their study, including the cause of faster heat penetration so that it can be reduced the processing time. The reduced process time affects in a better quality of the product. The other food from India examined was dairy dessert (kheer), which was known as a traditional milk product of South East Asia, in the form of cooked rice grains in creamy-sweetened concentrated milk. They used various values of $\mathrm{F}_{0}$ (12.4-14.8 minutes) and discovered it was still in good condition for 150 days of storage at $37^{\circ} \mathrm{C}$. The temperature of the rotary retort was operated in a steamair mixture set at $121.1^{\circ} \mathrm{C}$ at the pressure of 1.05 bar and an overpressure of 2.1 bar. Kheer product had a shelf-life of 5 months without refrigeration based on the study with the total process time (B value) ranged from 14.9- 21.5 minutes. Another retort food from India was also being examined the characteristic of textural and sensory of freshwater prawn in curry medium using retort pouch [11]. They processed the samples with a temperature of $116^{\circ} \mathrm{C}$ and reached the $\mathrm{F}_{0}$ value of 6,8 , and 9 minutes, and from the organoleptic study, it was chosen that $F_{0}$ value of 7 minutes got the highest score.

Korean traditional fermented food was also estimated the shelf-life value by Lee et al. [24]. They found that based on the TBA value, the shelf-life time of the retorted food was greater than three years. Cheftel and Culioli [25] have also studied the effect of high pressure in meat, and they revealed that pressure treatment at $100-800 \mathrm{MPa}$ (approximately at 1000-8000 bar), the structure and proteins constituents of muscle were very sensitive to high pressure. Retorted food in need of supporting spaceflight was also done by Catauro and Perchonok [26] for various kinds of retorted pouch foods. For meat products, the longest for the shelf-life period was 2 and 8 years without refrigeration. This could be a good opportunity for Rendang from Indonesia to become one of the foods for space missions. Many traditional foods, such as Rendang from Indonesia [27]-[29] are expected to be 
widely consumed by people from various countries in the world with the right sterilization process. Rendang is a traditional Indonesian food that has a potential long shelf-life value by its spices used during the process [30]. Retort food has become an interesting study for space missions and military diet, fast food for modern society, and food for poverty and disaster.

Dario Friso [31] studied mathematical modeling to verify the destruction of the desired microbes. The mathematical procedure can replace the Stumbo 57 table with a spreadsheet. Evaluation of food thermal processes using Neural Network was also developed to predict thermal process evaluation using the parameters of $g$ and $f_{h} / U$. Artificial Neural Networks (ANN) to complete sterilization by computerizing Sablani and Shayya [32] have also carried out the thermal method of the Stumbo process. They studied two different ANN models that called ANN for the parameter $\mathrm{g}$ (the difference between retort temperature and food center temperature) and ANNFU for parameter $f_{h} / U$ (ratio of heating rate index with sterilization value). Simpson et al. [33] studied the development of a broader application of the General Method in calculating thermal processes. The Revisited General Method (RGM) provides the same calculation as the Formula Method (FM) but with more accuracy. RGM always overestimates processing time with the proposed method, and for FM, errors are found around $10-20 \%$ or more.

A review of the Formula Ball Method has also been carried out by Simpson et al. [33]. They confirmed that shifting the zero time in the Ball formula method was not necessary because even though zero time was chosen, the calculation will always reflect the CUT effect. Improved methods for calculating the sterilization process using the concept of sterilization ratios have been studied by Steele and Board [34]. They proposed four advantages of the method developed, such as the method that can be used for any temperature scale for the same scale used in determining the sterilization ratio. The value of $\mathrm{z}$ was included in the sterilization ratio so that the table used was less than the other methods. The table could be used for any $\mathrm{z}$ value. So, the calculation was more general; tables were easier to reduce to simple estimates. The selection of integration boundaries ignored errors in tabulated values. Stoforos et al. [35] also tried to simplify Ball's original formula by replacing the use of tables fh / $\mathrm{U}$ vs. log g using two equations that have caused negligible errors. He also gave explicit expressions according to the Ball assumption for the relation $\mathrm{f}_{\mathrm{h}} / \mathrm{U}$ vs. $\mathrm{g}$ for $\mathrm{g}$ less than $0.1^{\circ} \mathrm{F}$.

The Original Ball Formula method is a classic method used until now, regardless of the reading patterns of logarithmic tables and tables, which are usually difficult to reproduce [35]. The method is still a popular method and an acceptable method for calculating the sterilization process until now because the basic principles used are easy to understand. The use of General Methods and Formula Methods is still interesting to study the basic principles of thermal processes. The General Method was first introduced by Bigelow and reviewed by Simpson et al. [36] with the basic equation as follows:

$$
L R=10(T-121,1 / z)
$$

$$
\begin{gathered}
\mathrm{F} 0 \text { partial }=\frac{[\operatorname{Lr}(\mathrm{n})+\operatorname{Lr}(\mathrm{n}-1)]}{2} \times \Delta \mathrm{t} \\
\mathrm{F} 0=\int_{t o}^{t} \operatorname{Lr} d t
\end{gathered}
$$

In this study, the sterilization process of beef Rendang packaged in retort pouch packages was evaluated using the Formula Ball Method to get the $\mathrm{F}_{0}$ value and then compared with the results of the General Method and the experimental results. The $\mathrm{F}_{0}$ value obtained from Formula Ball Method was then used to calculate the thermal process scenario using the reference temperature and the desired $\mathrm{F}_{0}$ value. Researches about traditional food were plentiful, especially for Asian food; however, the use of Formula Method to predict further to various process time $\left(\mathrm{P}_{\mathrm{t}}\right)$ in many scenarios option were still limited.

\section{MATERIAL AND METHOD}

Beef Rendang from Uni Upik Restaurant Yogyakarta, Indonesia, was used as an ingredient for the Ready-to-Eat Meal product. Beef Rendang, as a traditional food from Indonesian Minangkabau was made by drying beef cooked together with seasoned coconut milk. Methods for the sterilization process and the related results have been studied in previous studies [27]-[29], and registered in Indonesian patent number P00201708373 [37]. Beef Rendang was weighed separately between beef meat and the dressing, 60 gr each, with a total weight of 120 for both meat and the dressing using Digital Scale Camry. The samples then sealed using a vacuum sealer in brand VAC-STAR 2000CSI, 0,74 $\mathrm{kWH}, 50 \mathrm{~Hz}, 1.9 \mathrm{~A}, \mathrm{~V} 3 \times 380$, and then sterilized using ZonGon Overpressure Retort. In this study, the sterilization process chosen was using a 1.3 bar with the pressure hold for 40 minutes. Beef Rendang was packed in a four-layer PET / Nylon / Modified Aluminum / CPP retort bag (130x180 $\mathrm{mms}$ ). To ensure adequate sterilization, the value of $\mathrm{F}_{0}$ was examined through Data Logger Ellab CTF 9004 with the DC-Input of $1.2 \mathrm{~A}, 12 \mathrm{~V}$, and T maximum of $350^{\circ} \mathrm{C}$ and the accuracy of $0.1^{\circ} \mathrm{C}$ which integrated with system to calculate lethality, so it functioned also as the $\mathrm{F}_{0}$-meter $(\mathrm{T}$ ref $=$ $121,1^{\circ} \mathrm{C}$ and $\mathrm{z}$ value $=10^{\circ} \mathrm{C}$ ). The Heat Penetration Test was done using the Data Logger so we could get the temperature profile by the Data Logger and the $\mathrm{F}_{0}$ value, which was printed on thermo-paper together with the temperature data. Probes of the Data Logger were mounted precisely in the middle of the system to assure that the thermal process reached the slowest heating zone of the system. In this research, we used triplicate trials, and the data used was the worst scenario among them to assure the minimum process achieved to comply with the minimum $\mathrm{F}_{0}$.

The lethality value by temperature profile examined using The General Method developed by many researchers whose Simpson et al. [36] was one of them and also used the Ball Formula reviewed by Simpson et al. [33] to get $F_{0}$ value from temperature profile. The temperature profile was plotted to the logarithmic heating curve [(Tr-T) vs time] to get the parameters needed to estimate the $\mathrm{F}_{0}$ value. After we get the $\mathrm{F}_{0}$ value predicted by the General Method and Ball Formula, the values were compared. To make the further plan of process scenarios we used Ball Formula based on the logarithmic heating curve. The development of the Formula 
Method used in this study was published by [38] with the basic equation steps below:

$$
\begin{gathered}
\mathrm{jl}=(0,6 \times \mathrm{CUT}) \\
\mathrm{j}=\frac{j l}{T r-T} \\
\mathrm{Fi}=10^{\frac{(250-T r)}{z}} \\
\log \mathrm{g}=\log \mathrm{jl}-\frac{B}{f_{h}} \\
\mathrm{~F} 0=\frac{f_{h}}{\left(f_{h} /{ }\right) F_{i}} \\
\mathrm{Fi}=10^{\frac{(250-T r)}{z}} \\
\frac{f_{h}}{U}=\frac{f_{h}}{f_{0} \times f_{i}} \\
\mathrm{~B}=\mathrm{fh}(\log \mathrm{jl}-\log \mathrm{g}) \\
\mathrm{B}=\mathrm{Pt}+0,4 \mathrm{CUT}
\end{gathered}
$$

To estimate the $\mathrm{F}_{0}$ value of the system, we used formula (4), (5), (6), (7), (10), and (8). To estimate the $B$ and $P_{t}$ value, we used formula (4), (5), (6), (10), (7), (11), and (12). The $F_{0}$ value was estimated using $\mathrm{T}_{\mathrm{r}}$ target of $253^{\circ} \mathrm{F}\left(122.7^{\circ} \mathrm{C}\right)$ and $250^{\circ} \mathrm{F}\left(121.1^{\circ} \mathrm{C}\right)$ in $\mathrm{F}_{0}$ value target of $4,5,8,10$, and 12 minutes. Through these estimation scenarios, we designed the scheduled process time for Beef Rendang inside Retort Pouch Packaging with the sterilization process using a Pressure-controlled retort in achieving the commercially sterile product.

\section{RESULTS AND DISCUSSION}

This study was a series of previous studies [28], [29]. Rendang is a retort bag heated by steam in a retort with pressure control. Lethality $\left(\mathrm{F}_{0}\right)$ from the Rendang inside retort pouch packaging has been explained in that previous study. In this study, the heat penetration test was reexamined because the study was done in a different batch from the previous. The result of the heat penetration test was one of the results of three replications selected based on the lowest lethal value to achieve the worst scenario of the process schedule. The lethality was derived from triplicate trials is $5.91,8.31$, and 11.7 minutes. Figure 1 shows the results of the heat penetration test by the $F_{0}$ value of 5.91 minutes.

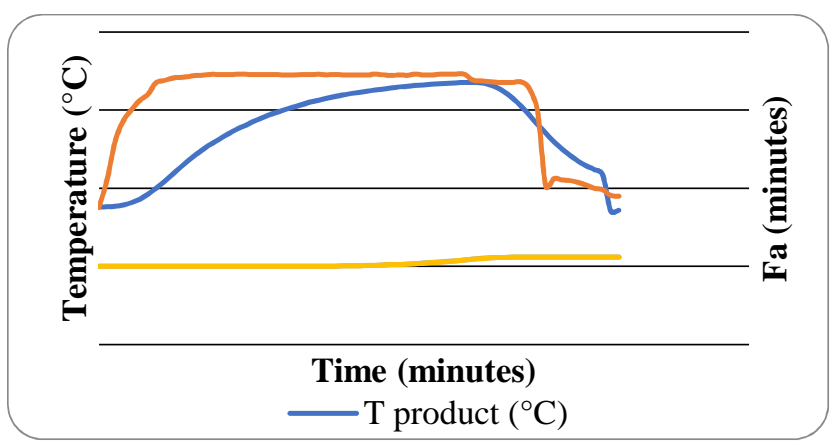

Fig. 1 Result of a heat penetration test of Rendang retort pouch (1,3 bar - 40 minutes)
From Figure 1 above, we could see that the retort temperature above $121^{\circ} \mathrm{C}$ was held for at least 28 minutes. The estimated temperature of the retort was $122.7^{\circ} \mathrm{C}$. The time is shown (CUT) of this process was 18 minutes. The value of sterilization using the General Method calculation was also evaluated. From the graph in Figure 1 above we could see that the General Method predicts the value of $F_{0}$ (Fa) closely and almost produces a value of $\mathrm{F}_{0}$, which was the same as the observed data. The value was 5.88 minutes using the General Method, while the observed data for $F_{0}$ was 5.91 minutes.

The temperature along the thermal process was then plotted into a semi-logarithmic graph to find the value of $j_{1}$ (the difference between the retort temperature and false initial temperature) and $f_{h}$ (the time required by the heating curve to change by one log cycle). The logarithmic heating curve could be seen in Figure 2 below.

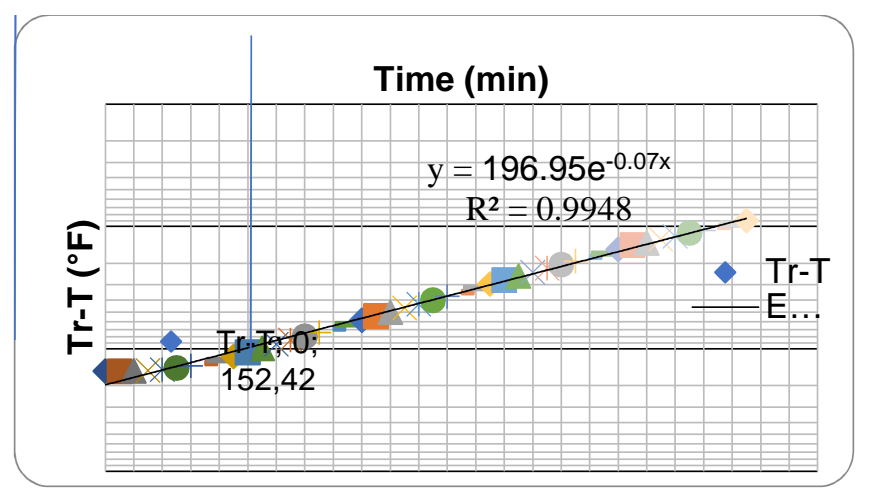

Fig. 2 Logarithmic Heating Curve of Rendang Pouch (1,3 bar - 40 minutes)

Figure 2 shows the Rendang Pouch heating curve that was processed using a horizontal still retort with a pressure of 1.3 bar hold for 40 minutes. In this study, the retort used was a pressure control retort. Through this calculation, the author wants to describe pressure control into time control, which was always the standard in the $12 \mathrm{D}$ sterilization process concerning the thermal death time of decomposing bacteria in temperature changes. This pressure control process when equated with the concept of the value $\mathrm{F}_{0}$, is attempted to be solved through this research.

TABLE I

CAlCulation RESUlt of $\mathrm{F}_{0}$ (MINUTES) USING Formula Method $\left(\mathrm{T}_{\mathrm{R}}=252,86^{\circ} \mathrm{F} ; \mathrm{P}_{\mathrm{T}}=27\right.$ MINUTES; CUT $=18$ MINUTES $\left.; \mathrm{J}_{\mathrm{L}}=93^{\circ} \mathrm{F}\right)$

\begin{tabular}{|c|l|l|}
\hline No & Formula & Result \\
\hline 1 & $\mathrm{j}_{1}=(0.6 \times \mathrm{CUT})$ & 10.8 \\
\hline 2 & $\mathrm{j}=\frac{j l}{T r-T}$ & 0.611 \\
\hline 3 & $\mathrm{~F}_{\mathrm{i}}=10^{\frac{(250-T r)}{z}}$ & 0.695 \\
\hline 4 & $\log \mathrm{g}=\log \mathrm{j} 1-\frac{B}{f_{h}}$ & 0.932 \\
\hline 5 & $\mathrm{f}_{\mathrm{h}} / \mathrm{U}$ & 9.18 \\
\hline 6 & $\mathrm{~F}_{0}=\frac{f_{h}}{\left(f_{h} / U\right) F_{i}}$ & $\mathbf{5 . 1 7}$ \\
\hline
\end{tabular}

From Figure 2 it was found that the value of $\mathrm{j}_{1}$ was $93^{\circ} \mathrm{F}$, and the value of $f_{h}$ was 33 minutes. After calculating the 
equations of (4), (5), (6), (7), (10), and (8), the results were presented in Table 1.

According to the calculation of the graph and formula used, the value of $\mathrm{F}_{0}$ was 5.17 minutes. This value was smaller than the $\mathrm{F}_{0}$ value derived from the observation data, which was 5.91 minutes; maybe it was caused by several errors that have been evaluated by Stoforos [35]. Smith and Tung [38] also examined the probability of errors in 5 different methods, which revealed that the biggest error was when $g$ value was large. The ratio of the packaged-food system's height to diameter approached 1 (one). From the calculated $\mathrm{F}_{0}$ value with the Formula Method, a scenario for thermal processing was planned. In Table 2 and Table 3 the $\mathrm{T}_{\mathrm{r}}$ and $\mathrm{F}_{0}$ targets were set, and then the total processing time and operator time were calculated.

TABLE II

CAlCulation RESUlt OF B AND $\mathrm{P}_{\mathrm{T}}$ (MINUTES) USING Formula METHOD $\left(\mathrm{T}_{\mathrm{R}} \mathrm{TARGET}=253^{\circ} \mathrm{F} ; \mathrm{CUT}=18\right.$ MINUTES $; \mathrm{J}_{\mathrm{L}}=93^{\circ} \mathrm{F} ; \mathrm{F}_{0}$ TARGET $=4$ MINUTES $)$

\begin{tabular}{|c|l|l|}
\hline No & Formula & Result \\
\hline 1 & $\mathrm{j}_{1}=(0.6 \times$ CUT $)$ & 0.61 \\
\hline 2 & $\mathrm{j}=j l /(\operatorname{Tr}-T)$ & 93.1 \\
\hline 3 & $\mathrm{~F}_{\mathrm{i}}=10^{\wedge}(((250-T r)) / z)$ & 0.681 \\
\hline 4 & $\mathrm{f}_{\mathrm{h}} / \mathrm{U}=\mathrm{f}_{\mathrm{h}} /\left(\mathrm{F}_{0} \times \mathrm{F}_{\mathrm{i}}\right)$ & 12.1 \\
\hline 5 & $\log \mathrm{g}$ & 0.996 \\
\hline 6 & $\mathrm{~B}=\mathrm{f}_{\mathrm{h}}(\log \mathrm{jl}-\log \mathrm{g})$ & $\mathbf{3 3}$ \\
\hline 7 & $\mathrm{P}_{\mathrm{t}}=\mathrm{B}-0.42$ CUT & $\mathbf{2 5}$ \\
\hline
\end{tabular}

From Table 2 we could see that $P_{t}$ value derived from the estimation was in the amount of 25 minutes for $T_{r}$ target value of $253^{\circ} \mathrm{F}$ and $\mathrm{F}_{0}$ target of 4 minutes.

TABLE III

CAlCUlation RESUlt OF B AND $\mathrm{P}_{\mathrm{T}}$ (MINUTES) USING FoRMUla METHOD $\left(\mathrm{T}_{\mathrm{R}} \mathrm{TARGET}=250^{\circ} \mathrm{F} ; \mathrm{CUT}=18\right.$ MINUTES $; \mathrm{J}_{\mathrm{L}}=93^{\circ} \mathrm{F} ; \mathrm{F}_{0}$ TARGET $=4$ MINUTES $)$

\begin{tabular}{|c|l|l|}
\hline No & Formula & Result \\
\hline 1 & $\mathrm{j}_{\mathrm{l}}=(0.6 \times$ CUT $)$ & 0.61 \\
\hline 2 & $\mathrm{j}=j l /(T r-T)$ & 93.1 \\
\hline 3 & $\mathrm{~F}_{\mathrm{i}}=10^{\wedge}(((250-T r)) / z)$ & 1.00 \\
\hline 4 & $\mathrm{f}_{\mathrm{h}} / \mathrm{U}=\mathrm{f}_{\mathrm{h}} /\left(\mathrm{F}_{0} \times \mathrm{F}_{\mathrm{i}}\right)$ & 8.25 \\
\hline 5 & $\log \mathrm{g}$ & 0.902 \\
\hline 6 & $\mathrm{~B}=\mathrm{f}_{\mathrm{h}}(\log \mathrm{jl}-\log \mathrm{g})$ & $\mathbf{3 6}$ \\
\hline 7 & $\mathrm{P}_{\mathrm{t}}=\mathrm{B}-0,42$ CUT & $\mathbf{2 8}$ \\
\hline
\end{tabular}

From Table 3 we could see that $\mathrm{P}_{\mathrm{t}}$ value derived from the estimation was in the amount of 28 minutes for $\mathrm{T}_{\mathrm{r}}$ target value of $250^{\circ} \mathrm{F}$ and $\mathrm{F}_{0}$ target of 4 minutes.

TABLE IV

CAlculation Result of B AND $\mathrm{P}_{\mathrm{T}}$ (MINUTES) USING FoRMUla Method $\left(\mathrm{T}_{\mathrm{R}} \mathrm{TARGET}=253^{\circ} \mathrm{F} ; \mathrm{CUT}=18\right.$ MINUTES $; \mathrm{J}_{\mathrm{L}}=93^{\circ} \mathrm{F} ; \mathrm{F}_{0} \mathrm{TARGET}=5$ MINUTES $)$

\begin{tabular}{|c|l|l|}
\hline No & Formula & Result \\
\hline 1 & $\mathrm{j}_{\mathrm{l}}=(0.6 \times$ CUT $)$ & 0.61 \\
\hline 2 & $\mathrm{j}=j l /(T r-T)$ & 93.1 \\
\hline 3 & $\mathrm{~F}_{\mathrm{i}}=10^{\wedge}(((250-T r)) / z)$ & 0.681 \\
\hline 4 & $\mathrm{f}_{\mathrm{h}} / \mathrm{U}=\mathrm{f}_{\mathrm{h}} /\left(\mathrm{F}_{0} \times \mathrm{F}_{\mathrm{i}}\right)$ & 9.69 \\
\hline 5 & $\log \mathrm{g}$ & 0.946 \\
\hline 6 & $\mathrm{~B}=\mathrm{f}_{\mathrm{h}}(\log \mathrm{jl}-\log \mathrm{g})$ & $\mathbf{3 4}$ \\
\hline 7 & $\mathrm{P}_{\mathrm{t}}=\mathrm{B}-0.42$ CUT & $\mathbf{2 7}$ \\
\hline
\end{tabular}

From Table 4 we could see that $\mathrm{P}_{\mathrm{t}}$ value derived from the estimation was in the amount of 27 minutes for $\mathrm{T}_{\mathrm{r}}$ target value of $253^{\circ} \mathrm{F}$ and $\mathrm{F}_{0}$ target of 5 minutes.

TABLE V

CAlCUlation RESUlt OF B AND $\mathrm{P}_{\mathrm{T}}$ (MINUTES) USING FoRMUla METHOD $\left(\mathrm{T}_{\mathrm{R}}\right.$ TARGET $=253^{\circ} \mathrm{F} ; \mathrm{CUT}=18$ MINUTES $; \mathrm{J}_{\mathrm{L}}=93^{\circ} \mathrm{F} ; \mathrm{F}_{0}$ TARGET $=8$ MINUTES $)$

\begin{tabular}{|c|l|l|}
\hline No & Formula & Result \\
\hline 1 & $\mathrm{j}_{\mathrm{l}}=(0.6 \times \mathrm{CUT})$ & 0.61 \\
\hline 2 & $\mathrm{j}=\frac{j l}{T r-T}$ & 93.1 \\
\hline 3 & $\mathrm{~F}_{\mathrm{i}}=10^{\frac{(250-T r)}{z}}$ & 0.681 \\
\hline 4 & $\mathrm{f}_{\mathrm{h}} / \mathrm{U}=\mathrm{f}_{\mathrm{h}} /\left(\mathrm{F}_{0} \times \mathrm{F}_{\mathrm{i}}\right)$ & \\
\hline 5 & $\log \mathrm{g}$ & 6.057 \\
\hline 6 & $\mathrm{~B}=\mathrm{f}_{\mathrm{h}}(\log \mathrm{jl}-\log \mathrm{g})$ & 0.808 \\
\hline 7 & $\mathrm{P}_{\mathrm{t}}=\mathrm{B}-0,42 \mathrm{CUT}$ & $\mathbf{3 1}$ \\
\hline
\end{tabular}

From Table 5 we could see that $P_{t}$ value derived from the estimation was in the amount of 31 minutes for $\mathrm{T}_{\mathrm{r}}$ target value of $253^{\circ} \mathrm{F}$ and $\mathrm{F}_{0}$ target of 8 minutes.

TABLE VI

CALCUlation RESUlt OF B AND $\mathrm{P}_{\mathrm{T}}$ (MINUTES) USING FoRMUla METHOD $\left(\mathrm{T}_{\mathrm{R}} \mathrm{TARGET}=253^{\circ} \mathrm{F} ; \mathrm{CUT}=18\right.$ MINUTES $; \mathrm{J}_{\mathrm{L}}=93^{\circ} \mathrm{F} ; \mathrm{F}_{0} \mathrm{TARGET}=10$ MINUTES)

\begin{tabular}{|c|l|l|}
\hline No & Formula & Result \\
\hline 1 & $\mathrm{j}_{1}=(0.6 \times \mathrm{CUT})$ & 0.61 \\
\hline 2 & $\mathrm{j}=j l /(\mathrm{Tr}-T)$ & 93.1 \\
\hline 3 & & \\
\hline 4 & $\mathrm{~F}_{\mathrm{i}}=10^{\wedge}(((250-T r)) / z)$ & 0.681 \\
\hline 5 & $\mathrm{f}_{\mathrm{h}} / \mathrm{U}=\mathrm{f}_{\mathrm{h}} /\left(\mathrm{F}_{0} \times \mathrm{F}_{\mathrm{i}}\right)$ & 4.85 \\
\hline 6 & $\log \mathrm{B}=\mathrm{f}_{\mathrm{h}}(\log \mathrm{jl}-\log \mathrm{g})$ & 0.73 \\
\hline 7 & $\mathrm{P}_{\mathrm{t}}=\mathrm{B}-0.42 \mathrm{CUT}$ & $\mathbf{4 1}$ \\
\hline
\end{tabular}

From Table 6 we could see that $P_{t}$ value derived from the estimation was in the amount of 34 minutes for $T_{r}$ target value of $253^{\circ} \mathrm{F}$ and $\mathrm{F}_{0}$ target of 10 minutes.

TABLE VII

THE CALCULATION RESUlT OF B AND $\mathrm{P}_{\mathrm{T}}$ (MINUTES) USING FORMULA METHOD $\left(\mathrm{T}_{\mathrm{R}} \mathrm{TARGET}=253^{\circ} \mathrm{F} ; \mathrm{CUT}=18\right.$ MINUTES $; \mathrm{J}_{\mathrm{L}}=93^{\circ} \mathrm{F} ; \mathrm{F}_{0}$ TARGET $=$ 12 MINUTES)

\begin{tabular}{|l|l|l|}
\hline No & Formula & Result \\
\hline 1 & $\mathrm{j}_{1}=(0.6 \times \mathrm{CUT})$ & 0.61 \\
\hline 2 & $\mathrm{j}=j l /(\operatorname{Tr}-T)$ & 93.1 \\
\hline 3 & $\mathrm{~F}_{\mathrm{i}}=10^{\wedge}(((250-T r)) / Z)$ & 0.681 \\
\hline 4 & $\mathrm{f}_{\mathrm{h}} / \mathrm{U}=\mathrm{f}_{\mathrm{h}} /\left(\mathrm{F}_{0} \times \mathrm{F}_{\mathrm{i}}\right)$ & \\
\hline 5 & $\log \mathrm{g}$ & 4.04 \\
\hline 6 & $\mathrm{~B}=\mathrm{f}_{\mathrm{h}}(\log \mathrm{j} 1-\log \mathrm{g})$ & $\mathbf{4 4}$ \\
\hline 7 & $\mathrm{P}_{\mathrm{t}}=\mathrm{B}-0,42 \mathrm{CUT}$ & $\mathbf{3 6}$ \\
\hline
\end{tabular}

From Table 7 we could see that $P_{t}$ value derived from the estimation was in the amount of 36 minutes for $\mathrm{T}_{\mathrm{r}}$ target value of $253^{\circ} \mathrm{F}$ and $\mathrm{F}_{0}$ target of 12 minutes. Table 8 shows a review of calculation results using many scenarios at retort temperatures of $253^{\circ} \mathrm{F}$ and $250^{\circ} \mathrm{F}$, with $\mathrm{F}_{0}$ targets varying 
from 4-12 minutes with the calculation of the step mentioned above.

TABLE VIII

B AND $P_{T}$ VALUES FOR VARIOUS SCENARIOS OF RENDANG POUCH THERMAL PROCESS

\begin{tabular}{|cccc|}
\hline $\begin{array}{c}\text { Temperature } \\
\left({ }^{\circ} \mathbf{F}\right)\end{array}$ & $\begin{array}{c}\mathbf{F}_{\mathbf{0}} \text { target } \\
(\text { minutes) }\end{array}$ & $\begin{array}{c}\mathbf{B} \\
(\text { minutes })\end{array}$ & $\begin{array}{c}\mathbf{P}_{\mathbf{t}} \\
(\text { minutes })\end{array}$ \\
\hline & 4 & 33 & 25 \\
& 5 & 34 & 27 \\
& 5 & 39 & 31 \\
& 8 & 4 & 34 \\
& 10 & 44 & 36 \\
\hline & 12 & 36 & 28 \\
$250{ }^{\circ} \mathrm{F}$ & 4 & 38 & 30 \\
& 5 & 43 & 36 \\
& 8 & 47 & 39 \\
& 10 & 50 & 42 \\
\hline
\end{tabular}

From Table 8, we could see that the value of $\mathrm{B}$ and $\mathrm{Pt}$ needed to be increased when we want to increase the target $\mathrm{F}_{0}$. Whereas when we want to use lower temperatures to achieve the same $F_{0}$ value, we need to heat the product in a longer period. In this study, we confirmed that the calculation of the process using the pressure-controlledretort could be treated the same as the time-controlled-retort. We just need to look carefully at what temperature $T_{r}$ remained in a stable condition; that was when the pressure held for a while. The stabile $T_{r}$ then be used as the $T_{r}$ for calculation in Formula Ball Method. The main part of the estimation was also when we captured the CUT value and the $\mathrm{J}_{1}$ value from the logarithmic heating curve. We need to look carefully at which point the $\mathrm{J}_{1}$ value from graph reading.

Steam sterilization techniques were safer in the risk of decompression than those High-Pressure Processing Techniques [39], [40]. The steam sterilization technique still became a good choice to preserve low acid foods, although it needs more studies in the effect of metal in it [41]. However, the use of the Ball Method still becomes a more compromised way to study the sterilization efficacy and could be more developed combined with software [42].

The following Figure 3 shows the samples of Rendang inside Retort Pouch Packaging. The samples were vacuumsealed packed in $60 \mathrm{gr}$ of meat and $60 \mathrm{gr}$ of dressing.

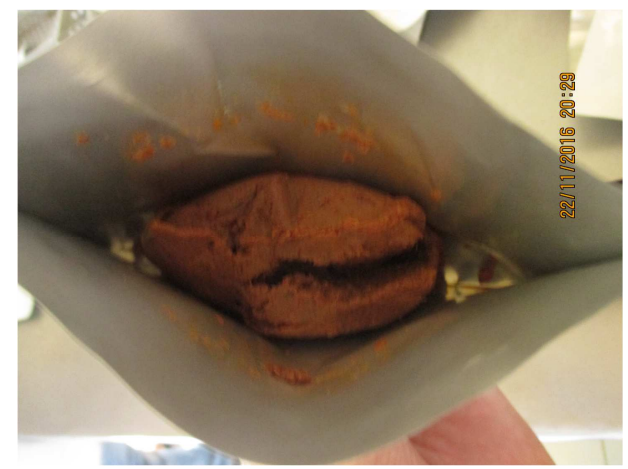

Fig. 3 Sample of Rendang inside Retort Pouch Packaging

Figure 4 shows the measurement of the $F_{0}$ value using $F_{0}$ meter. In this research, we used triplicate $F_{0}$ measurement, and the lowest value was used to calculated using General Method and Formula Ball Method.

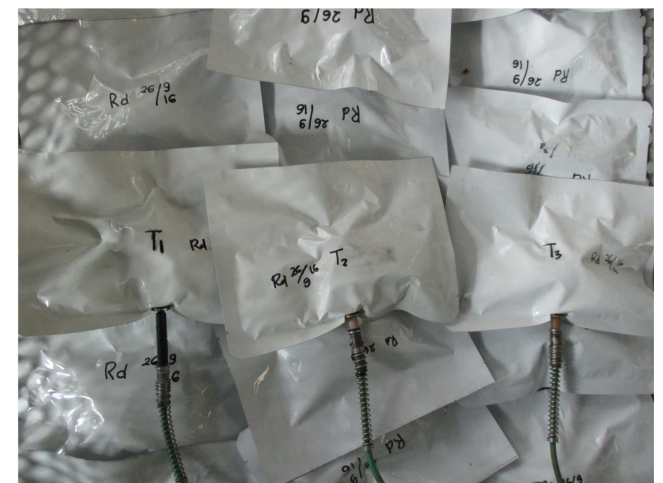

Fig. $4 \mathrm{~F}_{0}$-meter measurement inside Rendang Retort Pouch

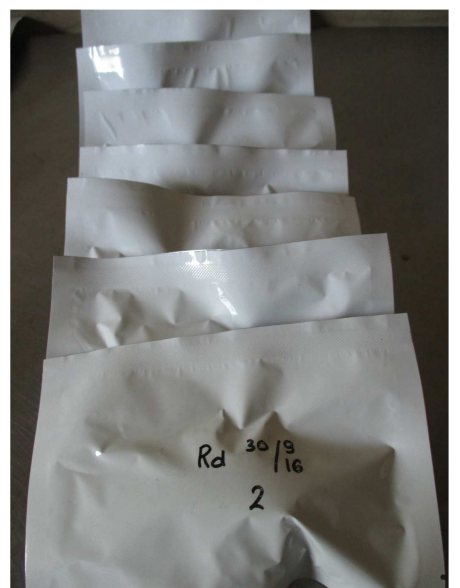

Fig. 5 Prototype of Rendang inside Retort Pouch Packaging

Figure 5 shows the prototype of Traditional Food Rendang as Ready-to-Eat Meal using Retort Pouch Packaging. The retort pouch was in the size of $120 \mathrm{gr}$ net weight, using a four-layer retort pouch (PET / Nylon / Modified Aluminum/CPP) in the dimension size of 130x180 mms.

\section{CONCLUSION}

The General Method and Formula Ball Method can be used to predict the $\mathrm{F}_{0}$ value of Rendang inside retort pouch packaging using a temperature profile. The results were by the results of observations, which were 5.88, 5.17, and 5.91 minutes for calculations using the General Method, Formula Method, and observation, respectively. The use of the Formula Ball Method is also still preferred because the steps are easily more understood in the basics of thermal processes so that it is easier to design a process time scenario. In this study, it was found that the value of Pt (processing time) Beef Rendang in a retort bag with a value of $\mathrm{F}_{0}$ designed 4,5 , 8,10 , and 12 minutes were $25,27,31,34$, and 36 minutes respectively for retort temperature $123^{\circ} \mathrm{C}\left(253^{\circ} \mathrm{F}\right)$. Whereas for a $121^{\circ} \mathrm{C}\left(250^{\circ} \mathrm{F}\right)$ retort temperature was $28,30,36,39$, 42 minutes, respectively. From these results, the writer hopes that the value derived could become additional information for designing the meat-curry- medium (Rendang)'s process schedule.

\section{NOMENCLATURE}

$\mathrm{T}$ process temperature ${ }^{\circ} \mathrm{F}$

$\mathrm{T}_{\text {ref }} \quad$ temperature reference, usually used $121.1^{\circ} \mathrm{C} \quad{ }^{\circ} \mathrm{F}$

$\mathrm{L}_{\mathrm{r}} \quad$ lethal rate 
$\mathrm{F}_{0} \quad$ sterilization value/sterilizing value of $121.1^{\circ} \mathrm{C}$

$\mathrm{j}_{1} \quad$ heating lag factor

CUT come up time

j dimensionless lag factor

$\mathrm{T}_{\mathrm{r}} \quad$ retort temperature

$\mathrm{T}$ product temperature

$F_{i} \quad$ period of heating in temperature $T_{r}$ equivalent with heating of 1 minute in $250^{\circ} \mathrm{F}$

$\mathrm{z}$ temperature heating difference which cause $\mathrm{D}$ value difference of $1 \log$ cycle

g difference of retort temperature with initial temperature

B total process time

$\mathrm{f}_{\mathrm{h}} \quad$ heating rate factors (related to slope of semi-log heat penetration curve)

$\mathrm{P}_{\mathrm{t}} \quad$ operator process time (time when retort reaches processing temperature until the steam is turned off)

$\min$

${ }^{\circ} \mathrm{F}$

$\min$

${ }^{\circ} \mathrm{F}$

${ }^{\circ} \mathrm{F}$

$\min$

${ }^{\circ} \mathrm{F}$

$\min$

$\min$

$\min$

\section{ACKNOWLEDGMENT}

The authors are grateful to Featured Activity Project (Kegiatan Unggulan) program by Indonesian Institute of Sciences/Lembaga Ilmu Pengetahuan Indonesia (LIPI) 2017 for funding this project during the period of 2016 and 2017.

\section{REFERENCES}

[1] A. Dinakaran, C. O. Mohan, S. K. Panda, C. N. Ravishankar, and T. K. S. Gopal, "Process Optimization for Ready to Eat Tapioca (Manihot esculenta Crantz) in High Impact Polypropylene Containers," J. Root Crop., vol. 43, no. 1, pp. 104-110, 2017.

[2] A. Dinakaran, M. C. O, S. K. Panda, R. C. N, and S. G. T. K, "Ready to Eat Cassava (Manihot esculenta crantz) in See Through Retort Pouch and Its Storage Stability," J. Packag. Technol. Res., vol. 1, no. 3, pp. 193-201, 2017.

[3] R. Mugale, S. B. Patange, V. R. Joshi, G. N. Kulkarni, and M. M. Shirdhankar, "Heat Penetration Characteristics and Shelf Life of Ready to Serve Eel Curry in Retort Pouch," Int. J. Curr. Microbiol. Appl. Sci., vol. 7, no. 2, pp. 89-100, 2018.

[4] R. S. Thakur and D. C. Rai, "Heat penetration characteristics and physico- chemical properties of retort processed shelf stable ready to eat palak paneer," Int. J. Chem. Stud., vol. 6, no. 4, pp. 949-954, 2018.

[5] P. S. Girish, L. Nath, R. Thomas, V. Rajkumar, and T. Alam, "Development of Shelf Stable Ready-to-Eat Pork Curry Using Retort Processing Technology," J. Packag. Technol. Res., vol. 2, no. 1, pp. 61-66, 2018.

[6] M. Ahmad Shah, S. John Don Bosco, S. Ahmad Mir, and K. V. Sunooj, "Evaluation of shelf life of retort pouch packaged Rogan josh, a traditional meat curry of Kashmir, India," Food Packag. Shelf Life, vol. 12, no. April, pp. 76-82, 2017.

[7] M. A. Adepoju, B. O. Omitoyin, C. O. Mohan, and A. A. Zynudheen, "Heat penetration attributes of milkfish ( Chanos chanos) thermal processed in flexible pouches: a comparative study between steam application and water immersion," Food Sci. Nutr., no. August, pp. $1-4,2016$.

[8] V. Abhishek, K. R, J. George, N. S, L. J.H, K. T, M. N, and N. S, "Development of retort process for ready-to-eat ( RTE ) soy-peas curry as a meat alternative in multilayer flexible retort pouches," Int. Food Res. J., vol. 21, no. 4, pp. 1553-1558, 2014.

[9] R. Tripathi and N. Nath, "Determination of Thermal Process Requirements for Baked Soybeans Canned in Brine and Tomato Sauce - A Comparative Study of the Methods of Process Calculatio.pdf," J. Food Sci. Technol., vol. 40, no. 1, pp. 11-16, 2003.

[10] V. Chandrasekar, T. K. S. Gopal, and R. D. Rai, "Heat Penetration Characteristics and Shelf-life Studies of Mushrooms in Brine Processed in Retort Pouches and Science," Packag. Technol. Sci., vol. 17, pp. 213-217, 2004.

[11] R. K. Majumdar, D. Roy, and A. Saha, "Textural and sensory characteristics of retort- processed freshwater prawn
( Macrobrachium rosenbergii ) in curry medium," Int. J. Food Prop., vol. 20, no. 11, pp. 2487-2498, 2017.

[12] P. Nalini, R. J. J. Abraham, V. A. Rao, R. N. Babu, T. N. Rajkumar, R. Rajkumar, and R. S. Kathiravan, "Shelf-Life of Ready-To-Eat Retort Processed Pepper Chicken," Int. J. Curr. Microbiol. Appl. Sci., vol. 7, no. 03, pp. 832-840, 2018.

[13] K. Isaka, M. Shibata, M. Osawa, J. Sugiyama, and T. Hagiwara, "Effect of retort treatment on physicochemical properties of highamylose rice gel made by high-speed shear treatment," J. Cereal Sci., vol. 79, no. November, pp. 335-340, 2018.

[14] J. Xu, M. Zhang, B. Bhandari, and P. Cao, "Microorganism control and product quality improvement of Twice-cooked pork dish using $\mathrm{ZnO}$ nanoparticles combined radio frequency pasteurization," $L W T$ Food Sci. Technol., vol. 95, no. April, pp. 65-71, 2018.

[15] J. Xu, M. Zhang, P. Cao, B. Adhikari, and C. Yang, "Microorganisms control and quality improvement of stewed pork with carrots using $\mathrm{ZnO}$ nanoparticels combined with radio frequency pasteurization," Food Biosci., vol. 32, no. November, p. 100487 , 2019.

[16] S. Condón-Abanto, J. Raso, C. Arroyo, J. Lyng, and I. Álvarez, "Quality-Based Thermokinetic Optimization of Ready-to-Eat Whole Edible Crab (Cancer pagurus) Pasteurisation Treatments," Food Bioprocess Technol., vol. 12, no. 3, pp. 436-446, 2019.

[17] T. Grauwet and A. Shpigelman, "Headspace fingerprint as a potential multivariate intrinsic indicator to monitor temperature variation of thermal in-pack processes: A case-study on broccoli puree," Innov. Food Sci. Emerg. Technol., vol. 48, no. June, pp. 122-130, 2018.

[18] C. Romero, M. Brenes, P. García-serrano, E. Medina, and P. Garcíagarcía, "Packing black ripe olives in retortable pouches with different oxygen permeability," Food Packag. Shelf Life, vol. 20, no. April, p. 100323, 2019

[19] C. K. Kamalakanth, T. K. Srinivasa Gopal, and C. G. Joshy, "Thermal Processing Characteristics and Storage Studies of Readyto-Eat Fish-Incorporated Noodles in Semi-Rigid Container," $J$. Packag. Technol. Res., vol. 2, no. 3, pp. 211-222, 2018.

[20] J. Patel, S. Al-Ghamdi, H. Zhang, R. Queiroz, J. Tang, T. Yang, and S. S. Sablani, "Determining Shelf Life of Ready-to-Eat Macaroni and Cheese in High Barrier and Oxygen Scavenger Packaging Sterilized via Microwave-Assisted Thermal Sterilization," Food Bioprocess Technol., vol. 12, no. 9, pp. 1516-1526, 2019.

[21] A. Soni, J. Smith, A. Thompson, and G. Brightwell, "Microwaveinduced thermal sterilization-A review on history, technical progress, advantages and challenges as compared to the conventional methods," Trends Food Sci. Technol., vol. 97, no. January, pp. 433-442, 2020.

[22] D. Dimakopoulou-Papazoglou and E. Katsanidis, "Osmotic Processing of Meat: Mathematical Modeling and Quality Parameters," Food Eng. Rev., no. December, 2019.

[23] J. Ai, T. Witt, M. J. Gidley, M. S. Turner, J. R. Stokes, and M. R. Bonilla, "Modelling of Thermal Sterilisation of High-Moisture Snack Foods: Feasibility Analysis and Optimization," Food Bioprocess Technol., vol. 11, no. 5, pp. 979-990, 2018.

[24] E. L. Shin, S. Y. Park, Y.-G. Jeong, B.-C. Jo, M. Kim, and S.-D. Ha, "Quality evaluation and estimation of shelf life of retort-pouched tomato- based and Korean traditional fermented food-based sauces Quality evaluation and estimation of shelf life of retort-pouched tomato-based and Korean traditional fermented food-based s," Korean Soc Appl. Biol. Chem., vol. 58, no. 2, pp. 229-236, 2015.

[25] J. C. Cheftel and J. Culioli, "Effects of High Pressure on Meat: A Review," Meat Sci., vol. 46, no. 3, pp. 211-236, 1997.

[26] P. M. Catauro and M. H. Perchonok, "Assessment of the Long-Term Stability of Retort Pouch Foods to Support Extended Duration Spaceflight," J. Food Sci., vol. 71, no. 1, 2012.

[27] A. S. Praharasti, J. Nugroho, B. Rahardjo, and A. Nurhikmat, "Evaluation for Sterilization of Rendang Packaged by Flexible Retort Pouch using Finite Difference Method," in ISABE Proceedings, 2016, no. August, pp. C03-1-7.

[28] A. S. Praharasti, A. Kusumaningrum, A. Frediansyah, A. Nurhikmat, Y. Khasanah, and Suprapedi, "Lethality of Rendang packaged in multilayer retortable pouch with sterilization process," in AIP Conference Proceedings, 2017, vol. 1788.

[29] A. S. Praharasti, A. Kusumaningrum, Y. Khasanah, R. Nurhayati, A. Nurhikmat, A. Susanto, and S. Suprapedi, "Physicochemical Properties and its Relations of Beef Rendang inside Retort Pouch Packaging in Various Temperature Storage Conditions," in IOP Conf. Series: Earth and Environmental Science 251, 2019, p. 012043.

[30] M. Nurmufida, G. H. Wangrimen, R. Reinalta, and K. Leonardi, "Rendang: The treasure of Minangkabau," J. Ethn. Foods, vol. 4, pp. 
232-235, 2017.

[31] D. Friso, "The Check Problem of Food Thermal Processes: a Mathematical Solution," Appl. Math. Sci., vol. 9, no. 113, pp. 56155628, 2015.

[32] S. S. Sablani and W. H. Shayya, "Computerization of Stumbo's method of thermal process calculations using neural networks," $J$. Food Eng., vol. 47, no. 3, pp. 233-240, 2001.

[33] R. J. Simpson, S. F. Almonacid, M. M. Sanchez, A. A. Teixeira, B. Engineering, and F. R. Hall, "Ball' s Formula Method Revisited."

[34] R. J. STEELE and P. W. BOARD, "Thermal process calculations using sterilizing ratios," J. Food Technol., vol. 14, no. 3, pp. 227-235, 1979.

[35] N. G. Stoforos, “Thermal process calculations through ball's original formula method: A critical presentation of the method and simplification of its use through regression equations," Food Eng. Rev., vol. 2, no. 1, pp. 1-16, 2010.

[36] R. Simpson, S. Almonacid, and A. Teixeira, "Bigelow' s General Method Revisited:," J. Food Sci., vol. 68, no. 4, pp. 1324-1333, 2003.

[37] A. S. Praharasti, Suprapedi, A. Nurhikmat, A. Susanto, Y. Khasanah,
A. Frediansyah, R. Nurhayati, and A. Kusumaningrum, "Patent Registration Form," P00201708373, 2017.

[38] A. Tung, "Comparison of Formula Methods for Calculating," J. Food Sci., vol. 47, pp. 626-630, 1982.

[39] J. Sterr, B. S. Fleckenstein, and H. C. Langowski, "The Theory of Decompression Failure in Polymers During the High-Pressure Processing of Food," Food Eng. Rev., vol. 10, no. 1, pp. 14-33, 2018

[40] N. A. Fauzi, M. M. Farid, and F. Silva, "An insight on the relationship between food compressibility and microbial inactivation during high pressure processing," J. Food Sci. Technol., vol. 54, no. 3, pp. 802-809, 2017.

[41] G. K. Deshwal and N. R. Panjagari, "Review on metal packaging: materials, forms, food applications, safety and recyclability," J. Food Sci. Technol., no. November, 2019.

[42] W. R. M. Zamora, M. J. S. Chero, and J. A. S. Chero, "Software for the Determination of the Time and the F Value in the Thermal Processing of Packaged Foods Using the Modified Ball Method," Springer Nat. Switz., vol. 1131, no. January, pp. 498-502, 2020. 